\title{
Differences between students and non-students' willingness to donate to a charitable organisation
}

Dr Robin Pentecost

Lecturer, Department of Marketing, Griffith University, Logan Campus, University Drive, Meadowbrook.

Queensland, 4043. Australia.

Email: r.pentecost@griffith.edu.au

Tel: 61733821095

Dr Lynda Andrews, Lecturer, School of Advertising, Marketing and Public Relations, Queensland University of Technology, Gardens Point Campus, P.O. Box 2434 Brisbane.

Queensland. 4001. Australia

Email: l.andrews@qut.edu.au

Tel: 61731384203 Fax: 61731381811 


\title{
Differences between students and non-students' willingness to donate to a charitable organisation
}

\begin{abstract}
This paper reports on a comparative study of students and non-students that investigates which psycho-social factors influence intended donation behaviour within a single organisation that offers multiple forms of donation activity, and which media channels are more important to encourage donation. A self-administered survey instrument was used and a sample of 776 respondents recruited. Logistic regressions and a Chow test were used to determine statistically significant differences between the groups. For donating money, importance of charity and attitude towards charity influence students, whereas only importance of need significantly influences non-students. For donating time, no significant influences were found for non-students; however, importance of charity and attitude towards charity were significant for students. Importance of need was significant for both students and non-students for donating goods, with importance of charity also significant for students. Telephone and television channels were important for both groups. However, Internet, email and short messaging services were more important for students, providing opportunities to enhance this group's perceptions of the importance of the charity, and the importance of the need, which ultimately impacts on their attitudes towards the charity. These differences highlight the importance of charities focusing on those motivations and attitudes that are important to a particular target segment and communicating through appropriate media channels for these segments.
\end{abstract}

Keywords: motivations, attitudes and intentions towards donation activities, media communication sources, student and non-student samples 


\section{Introduction}

There is a growing body of evidence that shows people are giving less to charities, that donations are stagnating in many developed countries, and that there is a decline in altruism and philanthropy, particularly in younger people (Kottasz, 2004a; Schegelmilch et al., 1997; Smith, 1999). At the same time, the size and types of charitable organisations continue to grow and change (Kottasz, 2004a; Schegelmilch et al., 1997). As a result, questions are being raised as to how well the general public understands modern charities, particularly in terms of how they go about their fundraising and other donation activities (Saxton, 2004). Additionally, charities are recognising the importance of marketing strategies to improve their ability to function effectively (Gwin, 1990) and thus a market orientation is becoming more apparent (Balabanis et al., 1997). Also of note is that professional marketers and academic researchers are now being employed to work with charitable organisations in preparing fundraising campaigns targeted to specific segments. These influences provide greater opportunities for the application of scientifically rigorous methodologies and analyses to better understand donors (Popovsky, 2006), which ultimately will guide marketing strategies aimed at specific constituent groups to improve outcomes (Gwin, 1990).

Much of the extant research focuses on single forms of donation behaviour, such as blood donations (e.g., Barkworth et al., 2002; France et al., 2007; Giles et al., 2004). There is limited empirical research examining other forms of donation behaviour, such as philanthropic giving (Grace and Griffin, 2006; Kottasz, 2004a, 2004b), face-to-face donation (Sargeant and Jay, 2003; Schegelmilch et al., 1997) and volunteering (Smith, 1999). Moreover, extant research does not examine consumer donation behaviour towards a single organisation that offers a range of donation activities (e.g., blood donations, volunteering, monetary donations and goods). Thus, there is a gap in the current literature seeking insights into consumer behaviour towards multiple donation activities within a single organisation.

Predominantly, existing research into consumer donation behaviour focuses on how to segment this market based on socio-demographic characteristics. For example, current studies investigate how age, gender and levels of affluence (e.g., Kottasz, 2004a, 2004b; Schegelmilch et al., 1997) and the donation behaviour of current and lapsed donors (e.g., Sargeant and Jay, 2003; Mathews et al., 2007). Profiling donors based on their sociodemographic characteristics is problematic in the longer term because current research suggests that older socio-economic groups are more likely to donate, but does not indicate why younger socio-economic groups do not. A number of studies have examined, with varying degrees of focus, what internal and external factors influence attitudes and motivations towards making donations (e.g., France et al., 2007; Giles et al., 2004; Lee et al., 1999; Mathew et al., 2007; Schegelmilch et al., 1997). The way to achieve this is through identifying their underlying psycho-social influences, such as motivations and attitudes, then focusing on those factors that are most important to the different target segments (Kottasz, 2004a, 2004b). Recognising the importance of understanding their target segments using consumer behaviour principles and theories and applying this to 
marketing strategies should be an imperative for charitable organisations (France et al., 2007; Giles et al., 2004; Grace and Griffin, 2006).

An additional area of interest in this paper relates to charitable organisations' use of media communication sources. While more personal approaches to donation, such as street collections or face-to-face fundraising, require donors to make more on-the-spot decisions (Sargeant and Jay, 2003), many fundraising campaigns use extensive integrated marketing campaigns to raise consumer awareness. This involves television, radio and other media channels, including new media technologies such as the Internet. Thus, research is emerging that examines which media communication sources are most appropriate or important for particular target segments (e.g., Hart, 2002; Goatman and Lewis, 2007; Mathew et al., 2007; Sargeant and Jay, 2003; Saxton, 2001).

Also of interest to this research are the possible comparative psycho-social influence differences between student and non-student samples on consumer donating behaviour and media use. Most of the studies reviewed used samples composed of either university students (e.g., France et al., 2007; Giles et al., 2004) or non-university students (e.g., Lee et al., 1999; Mathew et al., 2007). Because the findings are not specifically differentiated based on their relevance to the actual group sampled, it is not necessarily appropriate, nor statistically sound, to infer that findings for student samples would be relevant for target segments who are not students. Therefore, we question whether there are statistically significant differences between factors influencing students compared to non-students if these samples were located in the same piece of research. Since younger groups are perceived as being less philanthropic (Kottasz, 2004a), it is argued that the lack of empirical comparisons between these two groups is an important gap in the literature that needs to be addressed.

What is evident in the literature is that individuals' willingness to donate to various charitable organisations continues to be a topic of interest for both academics and professional practitioners. However, the discussion has suggested two gaps in the literature: (1) lack of research on one organisation with multiple donation activities, and (2) comparison of the psycho-social influences on donation behaviour and the importance of media communication sources between student and non-student samples. The study reported in this paper addresses these gaps by providing several points of differentiation from the existing literature. First, it focuses on consumer donation behaviour towards a single charitable organisation that encourages multiple forms of public donation activity. Second, it is a comparative study between university students and non-university students' attitudes and motivations towards donation behaviour. To date, no study examines whether attitudinal and motivational similarities or differences exist between a student and nonstudent samples' donation behaviour, nor how these factors influence each group's willingness to support a specific organisation's range of donation activities. It would also be useful to determine whether specific media channels are more important to different subsamples, such as students or non-students, particularly since electronic media gives consumers choice over what marketing messages they see (Saxton, 2001). This study, 
therefore, also includes an examination of the similarities and differences in the importance of media communication sources for these two groups.

\section{Review of the literature}

It has been suggested that people in contemporary society are becoming less philanthropic (e.g., Barkworth et al., 2002; Grace and Griffin, 2006; Kottasz, 2004a, 2004b; Schegelmilch et al., 1997). To explore this concern, a number of studies exist that seek insights into individuals' donor behaviour in terms of the internal and external factors that influence their voluntary helping behaviour. Findings from these studies suggest that the extent to which individuals' perceive the personal relevance of the charitable organisation, the importance of a specific donation activity, their level of involvement, or the conspicuousness of the donation will influence their donation behaviour (Grace and Griffin, 2006; Lee et al., 1999; Mathew et al., 2007; Schegelmilch et al., 1997). Lee et al. (1999) examined perceptions of the similarities and differences in three types of helping behaviour: volunteering time, giving money and donating blood. The findings suggest that donating blood was perceived as being different to giving time or money; moreover, donating blood was less frequent than the other two activities. Similarly, a covert qualitative study into blood donation behaviour also revealed insights into individuals' perceptions of these same types of donating behaviour (Mathew et al., 2007). The majority of respondents identified giving time as being the most important volunteer activity. While donating blood was perceived as a volunteer activity, this form of donation was perceived as more impersonal: it is "an easy way out" or "much like donating used clothes or money" (Mathew et al., 2007, p. 732).

Researchers have also examined what factors influence consumer behaviour towards blood donation as a specific donation activity. Misje et al. (2005) identified three primary factors: understanding (a positive experience associated with donating), value (altruistic or empathic reasons for donating), and esteem (volunteering in order to feel better about oneself). Giles et al. (2004) found that attitudes towards donating blood were influenced by self efficacy (an individual's belief that they have the confidence to perform the behaviour) and perceived control (an individual's judgment about the extent to which his/her decision to give blood is influenced by factors outside their control). France et al. (2007) also found that self efficacy was a strong predictor of intentions to donate blood. Personal moral norm or moral duty (a sense of moral obligation to society) was investigated in some studies, but only had a weak influence on attitude (e.g., Misje et al., 2005) and a non-significant influence on intentions (e.g., France et al., 2007). Social (a normative influence of family or friends that motivates the individual to volunteer) or subjective norms (France et al., 2007; Giles et al., 2004; Misje et al., 2005) were found to be a form of social influence on people's motivations to donate blood. Tescheulin and Lindenmeier (2005) also found that most donors in their study knew other donors and that this correlated with their willingness to donate.

The size and types of charitable organisations continue to grow and change over the decades (Saxton, 2004; Schegelmilch et al., 1997). As a result, questions are being raised as 
to how well the general public understand modern charities, particularly in terms of how they go about their fundraising and other donation activities. This, in turn, may lead to more cynical and less supportive reactions from the public (Saxton, 2004). Unfavourable attitudes towards a charitable organisation in terms of its efficiency or effectiveness may also influence people's attitudes towards and subsequent behaviour regarding making donations (Saxton, 2004; Kottasz, 2004b; Schegelmilch et al., 1997). Kottasz (2004b) examined whether affluent young professionals would prefer to donate to a reputable charity (i.e., a charity that they trust to be effective and efficient). While this preference was not significant in their research, the question remains as to whether negative perceptions about a charitable organisation also influences donation behaviours. Schegelmilch et al . (1997) found that these perceptions are an important factor in specific types of donations, such as door-to-door, street or church collections. Mathew et al. (2007) reported that the bad publicity about wasted blood donations following the September 11 World Trade Centre attacks influenced people's likelihood to donate blood; and by extension, the public perception of the agencies involved. This then raises an important question: to what extent do negative attitudes towards a charitable organisation's behaviour impact on people's willingness to donate?

As well as understanding people's motivations and attitudes towards supporting their causes, charity organisations also need to understand their target segments' responses to different methods of communicating these needs (Louie and Obermiller, 2000). People in contemporary society experience a wide variety of advertising tools) across multiple communication channels, including those facilitated through information communication technologies (ICTs). For charitable organisations, the importance of determining which segment of donors is using which media channels, and which media are considered most important, is an ongoing challenge. This becomes even more the case when considering the ICTs available for engaging with existing and potential donors, such as the Internet and email (Burt and Taylor, 2003; Goatman and Lewis, 2007; Hart, 2002), not to mention the mobile phone and the plethora of the new electronic media technologies such as blogs, MySpace, Facebook and YouTube.

While existing research into consumer media habits and their use for enhancement the fundraising campaigns is still nascent, some studies are available. Matthew et al. (2007) found that the respondents in their focus groups identified television and radio as appropriate media to encourage blood donation; however, this was balanced against their apparent lack of knowledge about the importance of the need. The researchers suggested that the reach of television and radio was limited and that organisations should start to explore the use of "novel avenues" (p. 734) such as billboards, electronic highway signs and advertising space on shopping trolleys. With the growth of new media technologies and their implications for the not-for-profit sector, some charities have been quicker than others to develop websites to communicate with their target communities of interest (Goatman and Lewis, 2007; Saxton, 2001). Moreover, the active use of these websites for particular donation activities has been highly variable (Goatman and Lewis, 2007). Sargeant and Jay (2003) examined respondents' preferred media for communications from charities after they had been recruited to make donations using face-to-face methods. The preference for 
direct mail was high, with the preference for email second, but trailing quite significantly ( $82 \%$ and 32\% respectively). Interestingly in this study, text messages were included but were the preferred communication method for only $3 \%$ of the respondents. It is argued, however, that charitable organisations that reach younger people through these media communication channels will benefit and that specific marketing campaigns that integrate these channels need to be developed for these segments (Saxton, 2001). It would also be useful to determine whether specific media channels are more important to different segments, particularly since electronic media gives consumers choice over what marketing communication messages they see (Saxton, 2001).

While the above discussion identifies what influences individuals' attitudes and motivations towards donating and their preferred choice of media communication sources, there may still be important differences between the samples obtained. One controversy over the years has been the use of students as subjects in applied marketing research (e.g., Burnett and Dunne, 1986; Gordon et al., 1986; Peterson, 2001). It has been found that personal characteristics can create differences between each of these groups (Miller et al., 1983). The use of student samples may then create apprehension about the ecological validity of the research in that students are not representative of the general population, thereby casting doubt upon the generalisability of the findings (Brunswick, 1955; Campbell and Stanley, 1963). Thus, students may be judged inappropriate subjects for research in applied disciplines (Gordon et al., 1986).

The studies reviewed earlier used samples composed of either university students [students] (e.g., France et al., 2007; Giles et al., 2004; Nonis et al., 1996) or non-university students [non-students] (e.g., Lee et al., 1999; Mathew et al., 2007; Tscheulin and Lindenmeier, 2005). None of the studies reported having a mixed sample of students and non-students. In previous studies reporting statistical tests of between-group differences, the majority of findings indicate that the results differ between student samples and non-students samples (e.g., Gordon et al., 1986). Thus, caution should be exercised when extending findings from studies using student samples to a non-student population, as student samples were found to be slightly more homogenous (Peterson, 2001). Therefore, replication of a study should be undertaken before attempting to generalise the findings from student samples to samples from the wider population. However, in the study reported here, these betweengroup differences are examined and compared to identify their influences on a range of donation behaviours.

\section{Research design}

This study is conducted within the organisational context of the Australian Red Cross, which has been responding to community needs since 1914 (Australian Red Cross, 2007). This organisation offers potential donors a range of activities, such as donating time [volunteering], money, and goods, as well as donating blood. However, this organisation was publicly criticised over how it spent the donations raised in a major appeal following a significant humanitarian crisis in 2002 (Day, 2003; Dept of Gaming and Racing, 2003). Subsequently, there was anecdotal evidence that some people would not be willing to make donations to the Red Cross again as a result (Day, 2003). While the impact of this incident 
is not specifically tested, this study examines both students' and non-students' attitudes towards the Red Cross and what other factors influence their intentions towards this charitable organisation's range of donation activities.

The study involved a quantitative research design using a self-administered survey instrument. Six items were used to measure donor motivation. Adapted from Harvey (1990), these items measure motivation based upon the perceived importance of charity. This importance relates to community values and explores the extent to which individuals perceive the charity to be worthwhile. Attitude towards charity was measured using items adapted from Richins (1983). These items measure general attitude towards an organisation and its offering. Importance of need was measured using items adapted from Mano and Oliver's (1993) need evaluation scale. Originally developed from Zaichowsky's (1985) involvement items, this scale evaluates the degree to which respondents perceive the need as being vital and necessary. Social values, identified as the individual's feelings of being part of a society, were measured using scales developed by Corfman et al. (1991). These items assessed socially-related values such as security, belongingness, and respectability in a person's life. This notion of social value is similar to that of Kottasz (2004b), who noted that young professionals felt a need to belong to their communities or to society. All items were measured on a 7 point Likert-type scale with anchor points of 1 (strongly disagree) and 7 (strongly agree). Behaviour was measured using two outcome variables: actual blood donation behaviour (measured by requesting a yes/no response for the following question: Have you ever given blood?) and behavioural intentions towards making other forms of donations to the Red Cross such as money, time and goods (measured using 1 [highly improbable] and 7 [highly probable]). Finally, respondents were asked to rate the degree of personal importance of a range of media communication channels. The Likert-type scale ranged from 1 (very unimportant) to 7 (very important).

Using an intercept technique and self administered survey, the sample was drawn from a coastal city with a significant university student population. To cover the question of ethics in research, a cover page was included with the questionnaire. This gave reassurance to the respondents that the research was anonymous and only the combined results of the survey were to be made known. No respondent was asked to give his or her name so the anonymity of the respondent would be assured. Respondents were also informed that there participation was completely voluntary and they could withdraw from the research at any time. A copy of the questionnaire can be found in appendix 1.

To remove potential biases, steps were taken to obtain similar sample demographics for both student and non-student respondents and similar gender and age characteristics, given that significant differences may be found between these demographic characteristics when donating blood (Nonis et al., 1996). To achieve this sampling was taken from areas both within and outside the university environment. The outside environment included shopping malls and other general public areas (e.g. dining areas, recreation areas, strip malls, etc) given that both students and non-students can be found within these areas. Table 1 shows $27 \%$ of the sample being obtained from within a university with the rest obtained from shopping malls (25\%) and general public areas (49\%). This resulted in a sample of 776 
respondents, of which 356 (46\%) were students comprised of 54\% males and $46 \%$ females and 420 (54\%) were non-students comprised of 58\% males and $42 \%$ females (refer table 2). The average age for both samples was 29-30 with a standard deviation of 11.6.

\section{ADD TABLE 1 (Sampling Environment) HERE ADD TABLE 2 (Sampling Distribution) HERE}

\section{$\underline{\text { Data analysis }}$}

Factor analysis and reliability tests were conducted on the multi-item constructs. Results show social values and importance of charity to have alphas $\geq .70$, while importance of need and attitude towards charity both have an alpha of .66. While these latter constructs are below the .70 level recommended by Nunnally and Bernstein (1994), given the small difference and that a figure between .6 and .7 may be considered as fairly reliable (Zikmund and Babin, 2007) these constructs were retained for further analysis.

Next, a logistic regression was run to evaluate actual behaviour (whether the respondent had given blood). This technique was chosen over cross-tabulation because it allows for each of the scalar predictor constructs (i.e., social values, importance of charity, importance of need, and attitude towards charity) as well as the categorical student / nonstudent variable to be included in the analysis. Results show a good fit for the logistic model. Using the log likelihood value (LLV) as a measure of error in model estimation (Hair et al., 1998), estimation was found to significantly increase $\left(\chi^{2}[5 \mathrm{df}]=29.98\right.$, sig. $=$ $.000)$ with the inclusion of the predictor variables ( $L L V=747.87)$ against the base assumption that they do not influence the estimate ( $\mathrm{LLV}=777.85)$. This was confirmed with fit between the actual model and predicted model, as indicated by the Hosmer and Lemeshow value, having an insignificant Chi-square $\left(\chi^{2}[8 \mathrm{df}]=10.52\right.$, sig. $\left.=.23\right)$. While a significant model was found, only $6.9 \%$ of the variance in the model may be explained by the model (Nagelkerke $\mathrm{R}^{2}=.069$ ). This variance may be explained primarily by whether the respondent was a student or not. Table 3 shows this predictor to have a significant effect (sig. $<.01$ ) on whether or not they had donated blood, with the results suggesting that the likelihood of having given blood is greater in non-students than students $(\mathrm{B}=.803$ : $\operatorname{Exp}(\mathrm{B})$ 2.23). The importance of this finding lies in the significant influence of this categorical predictor variable on behaviour, indicating potential differences between the demographic groups on donating behaviour.

\section{ADD TABLE 3 (Logistic Regression) HERE}

While the above analysis focuses on actual blood donating behaviour, also of interest is the intention towards other forms of donating. Using a grouping split to compare students and non-students on their intentions to donate money, time or goods, regression analysis was chosen over t-tests to reduce type 1 error (Hair et al., 1998). However, while regressions may indicate the significance of each independent variable for each group, they do not test 
whether these regressions are statistically significant between each group. One means to confirm this is through Chow tests. This approach tests for homogeneity or equality between subsets of coefficients to determine the differences between two regressions (Chow, 1960; Gujarati, 1995). For this test, the null hypothesis states that there are no structural changes in the parameters, that is, the slope of the predictors and the intercept are not significantly different between each group. The null hypothesis can be rejected where the calculated F statistic is greater than the critical F (Chow, 1960; Gujarati, 1995). Using the residual sum of squares (RSS) as the base for analysis, the model for testing this hypothesis is:

\begin{tabular}{ll} 
Where: & \multicolumn{1}{c}{$\mathrm{S}_{2} / \mathrm{k}$} \\
$\mathrm{F}$ & $\mathrm{S}_{1} /\left(\mathrm{n}_{1}+\mathrm{n}_{2}-2 \mathrm{k}\right)$ \\
$\mathrm{n}_{1}$ & $=$ calculated $\mathrm{F}$ \\
$\mathrm{n}_{2}$ & $=$ number of observations in Group 1 \\
$\mathrm{~S}_{1}$ & $=$ number of observations in Group 2 \\
$\mathrm{~S}_{2}$ & $=$ RSS for group 1 plus RSS for Group 2 \\
$\mathrm{k}$ & $=$ number of predictors
\end{tabular}

Table 4 shows significant structural differences between students and non-students on their intentions towards the various donation activities identified (donating money, time and goods]). Given these findings, and referring to the regression analyses in Table 5, the results suggest statistically significant differences between the two groups. As demonstrated, when it comes to donating money, both importance of charity and attitude towards charity have a significant influence for students (sig. $<$.05). However, for nonstudents only importance of need was found to be significant. No significant influences on donating time were found for non-students; however, importance of charity and attitude towards charity were again found to be significant for students. Importance of need was significant for both students and non-students when considering giving goods, with importance of charity also being significant for students. Social values were found to have no influence on intentions towards any of the donation activities for both groups in the sample.

\section{ADD TABLE 4 HERE ADD TABLE 5 HERE}

An important aspect of marketing is using the right communication channel for the identified target markets. Results of the media communication channels analyses reveal significant difference between the student and non-student groups regarding the importance of media. On a scale of $1-7$ with seven being very important, the telephone followed by television and email were found to be the most important communication media for both groups. However, email was found to be significantly more important for students $(\mathrm{m}=6.4$ : sig. $<.01)$ than non-students $(m=5.4)$. Newspapers, radio, and Internet were found to be 
somewhat important for both groups, although students were found to rate the Internet significantly more important $(\mathrm{m}=5.5$ : sig. $<.01)$ than non-students $(\mathrm{m}=4.7)$. The remaining media were rated as neither important nor unimportant through to somewhat important. Of note is the fact that students rated SMS significantly higher $(\mathrm{m}=5.0$ : sig. $<$ $.01)$ than non-students $(\mathrm{m}=4.3)$ as a form of media communication. These findings are shown in Table 6. Moreover, Figures 1, 2 and 3 graphically show the distribution of responses on the scale for each of the media communication channels that were significantly different between the two groups.

\author{
ADD TABLE 6 (Importance of Media) Here \\ ADD FIGURE 1 (Email) Here \\ ADD FIGURE 2 (Internet) Here \\ ADD FIGURE 3 (SMS) Here
}

\title{
Discussion and contributions
}

The identified differences between the student and non-student groups in the study contributes to and extends research that highlights the importance of charitable organisations' focusing their marketing efforts only on those motivations and attitudes that are important to a particular target segment or constituent group (Balabanis et al., 1997; Giles et al., 2002; Gwin, 1990). Moreover, the study identifies that these motivations and attitudes are not only different for a particular segment, but also dependent on what type of donation is being sought. Rather than identifying the best donors and asking them for more, regardless of the type of donation required, the current study highlights a more sustainable approach to engaging with actual and potential donors. Marketers, therefore, can encourage other segments or constituent groups to participate through identifying their underlying motivations and attitudes related to the form of donation activity required. They can then develop campaigns that more accurately resonate with these donor segments in ways that encourage them to participate appropriately.

For example, the findings suggest that charitable organisations should develop marketing communications that incorporate strategic messages focusing on the importance of the charity when trying to attract donations of money, time and goods from student groups. The findings also suggest that these messages, when combined with improving students' attitudes towards the charity, are likely to have the greatest positive effect on their willingness to donate money and time, but not goods. For the donation of goods, the importance of the charity, together with the importance of the need (for the donation), should be strategically combined into the marketing communications when engaging with students. For intentions to donate for the non-student group, the findings suggest that marketers should be developing strategic messages that focus on the importance of the need when seeking both money and goods.

Marketers working in charitable organisations need to ensure that their campaign messages are communicated through appropriate media channels for the target segments. In the current study, both groups indicated that telephone and television were important media 
communication sources, supporting Matthew et al.'s (2007) finding that many donor groups receive information about charity requirements through these channels. However, that study also suggested that some donor groups did not pick up on the importance of the need for the donation from these more traditional media sources - a motivation that was found to be important for both groups in this current study. The current study findings demonstrate that for the student group, the Internet, email and SMS were rated as being significantly more important compared to the non-student group. Marketers are continually encouraged to look at how they integrate forms of new electronic media into their marketing campaigns. These findings suggest that this is also an imperative for practitioners in the not-for-profit sector. The connections between the factors that influence the student group and their perceived importance of the Internet and email as media sources suggests that charitable organisations should be engaging this target market by encouraging them to visit their websites. Thus, marketers should develop strategies to drive traffic to the organisation's website where there should be greater opportunities for donor segments to interact with the charity's 'brand', such as reading success stories and learning more details about the type of work being undertaken. These brand engagement opportunities would enhance student group's perceptions of the importance of the charity and the importance of the need (for the donation). Additionally, the site can be used for relationship building by encouraging specific interactions between these visitors and the charity, such as encouraging them to sign up for newsletters, joining virtual communities or engaging with the charity's blogs or discussion groups. This deeper level of engagement can ultimately impact on the groups' attitudes towards the charity. As this relationship is strengthened, the organisation can then engage in email or SMS communication with the donor groups to continue building their support through ongoing online and offline interactions (Goatman and Lewis, 2007; Hart, 2002).

\section{Limitations and future research directions}

This study has several limitations. First, the accuracy of self reporting in the context of donation behaviour may be affected by social desirability (e.g., Louie and Obermiller, 2000). While the anonymity of the data collection may reduce this bias (Louie and Obermiller, 2000), future research should consider methods of confirming donation behaviour, such as respondents producing blood donation identification. Additionally, measures could be included relating to whether respondents have had the opportunity to donate in the recent past. Second, the respondents can be viewed as a convenience sample because they were recruited from one city that has a large university population. A national sample would provide greater generalisability of the findings. The results should also be considered in the light of the low adjusted $\mathrm{R}^{2}$ in the regressions. However, these regressions did yield significant results, which provide insights into similarities and differences in the motivations and attitudes that influence the two different groups and open up the possibilities for future research in this area.

In terms of future directions for research, of interest in the study is the lack of influence of social values on intentions towards any donation activities for either group. In the nonstudent group, this goes against the findings by Kottasz (2004b), who stated that young 
professionals felt a need to belong to their communities or to society. This disparity of results may be explained by the fact that the non-student group in this current study encompassed all forms of occupations over a wider age range, rather than just professionals. However, further research is required to confirm or refute these findings. Additionally, in terms of intentions to donate time, no significant influences were found for the non-student group. Given that this demographic is also likely to have less time on their hands, it makes intuitive sense that no influences were found for this form of donation. Further research could be conducted to establish whether those individuals who are unable to donate their time would be more likely to provide other forms of donations to compensate for this. Such research would be useful for single organisations that offer a number of different donation activities in which their target segments can become involved.

While the use of student samples may help in the development or testing of theories to predict or explain individuals' donation behaviour, the extent to which these findings can be generalised to non-student samples needs to be examined. This is important as the results reported in this study suggest that the findings may be quite different between the groups. While this study was confined to a specific organisation, the differences identified between the two groups would suggest the importance of including both student and nonstudent samples in studies to further increase the generalisability of future research findings.

A final area for future research in not-for-profit marketing is the extent to which practitioners should integrate new communication technologies into their marketing communications. The findings in this study showed that the student sample, which might also relate to young professionals, may be more likely to respond to charities that engage with them through the Internet. However, studies suggest that many charities are still not using their websites effectively for brand enhancement, online relationship building and ultimately online donations or fundraising (Goatman and Lewis, 2007). An additional area of research that should be undertaken is to investigate how charities can extend their marketing campaigns into areas of new media communication technologies, such as the use of Facebook, MySpace and You Tube, in order to engage with younger consumers (particularly Generation Y) who may be spending more time interacting with these new media than other technologies, such as the Internet, or traditional media, such as the television. 


\section{References}

Australian Red Cross. 2007. http://www.redcross.org.au/howyoucanhelp_default.htm [8 June 2007].

Balabanis G, Stables RE, Phillips HC. 1997. Market orientation in the top 200 British Charity organisations and its impact on their performance. European Journal of Marketing 31(8): 583-603.

Barkworth L, Hibbert S, Horne S, Tagg S. 2002. Giving at risk? Examining perceived risk and blood donation behaviour. Journal of Marketing Management 18: 905-922.

Burnett JJ, Dunne PM. 1986. An appraisal of the use of student subjects in marketing research. Journal of Business Research 4(August): 329-334.

Burt E, Taylor J. 2003. New technologies, embedded values and strategic change: Evidence from the U.K. voluntary sector. Nonprofit and Voluntary Sector Quarterly 32(1): 115-127.

Brunswick E. 1955. Representative design and probabilistic theory in a functional psychology. Psychological Review 62: 193-217.

Chow G. 1960. Tests for equality between sets of coefficients in two linear regressions. Econometrica 28(3): 591-604.

Corfman KP, Lehman DR, Narayanan SN. 1991. Values, utility, and ownership: Modeling the relationships for consumer durables. Journal of Consumer Research 67(Summer): 184204.

Campbell DT, Stanley JC. 1963. Experimental and Quasi-Experimental Designs for Research. Houghton-Mifflin: Boston.

Day K. 2003. Red Cross hurting after Bali appeal criticism. Transcript from ABC Radio. http://www.abc.net.au/pm/content/2003/s882004.htm [17 June, accessed 8 June 2007].

Dept of Gaming and Racing. 2003. Report of the Inquiry into the Red Cross Bali Appeal. http://www.olgr.nsw.gov.au/pdfs/red_cross_bali_appeal_rpt.pdf [8 June 2007].

France JL, France CR, Himawan LK. 2007. A path analysis of intention to redonate among experienced blood donors: An extension of the theory of planned behaviour. Transfusion 47(6): 1006-1013. 
Giles MC, McClenahan EC, Cairns E, Mallett J. 2004. An application of the theory of planned behaviour to blood donation: The importance of self-efficiency. Health Education Research 19(4): 380-391.

Goatman A, Lewis B. 2007. Charity E-volution? An evaluation of the attitudes of UK charities towards website adoption and use. International Journal of Nonprofit and Voluntary Sector Marketing 12(1): 33-46.

Gordon ME, Slade LA, Schmitt N. 1986. The science of the sophomore revisited: From conjecture to empiricism. The Academy of Management Review 11(1): 191-208.

Grace D, Griffin D. 2006. Exploring conspicuousness in the context of donation behaviour. International Journal of Nonprofit and Voluntary Sector Marketing 9(1): 9-27.

Gujarati DN. 1995. Basic Econometrics (3 ${ }^{\text {rd }}$ ed). McGraw Hill: Singapore.

Gwin JM. 1990. Constituent analysis: A paradigm for marketing effectiveness in the notfor-profit organization. European Journal of Marketing 24(7): 43-48.

Hair JF, Anderson RE, Tatham RL, Black WC. 1998. Multivariate Data Analysis (5 ${ }^{\text {th }}$ ed). Prentice-Hall: New Jersey.

Hart TR. 2002. ePhilanthropy: Using the Internet to build support. International Journal of Nonprofit and Voluntary Sector Marketing 7(4): 353-360.

Harvey JW. 1990. Benefit segmentation for fund raisers. Journal of the Academy of Marketing Science 18(Winter): 77-86.

Kottasz R. 2004a. How should charitable organisations motivate young professionals to give philanthropically? International Journal of Nonprofit and Voluntary Sector Marketing 11(2): 147-154.

Kottasz R. 2004b. Differences in the donor behaviour characteristics of young affluent males and females: Empirical evidence from Britain. Voluntas, International Journal of Voluntary and Nonprofit Organisations 15(2): 181-203.

Lee L, Piliavin JA, Call VR. 1999. Giving time, money, and blood: Similarities and differences. Social Psychology Quarterly 62(3): 276-291.

Louie TA, Obermiller C. 2000. Gender stereotypes and social desirability effects on charity donation. Psychology and Marketing 17(2): 121-136.

Mano H, Oliver RL. 1993. Assessing the dimensionality and structure of the consumption experience: evaluation, feeling, and satisfaction. Journal of Consumer Research 20(December): 451-466. 
Mathew SM, King MR, Glynn SA, Dietz S, Caswell S, Schreiber G. 2007. Opinions about donating blood among those who never gave and those who stopped: A focus group assessment. Transfusion 47(4): 729-735.

Miller GR, Fontes NE, Boster F J, Sunnafrank MJ. 1983. Methodological issues in legal communication research: What can trial simulations tell us? Communication Monographs 50: 33-46.

Misje AH, Bosnes V, Gasdal O, Heier HE. 2005. Motivation, recruitment and retention of voluntary non-remunerated blood donors: A survey-based questionnaire study. Vox Sanguinis 89: 236-244.

Nonis SA, Ford C, Logan L, Hudson G. 1996. College students behaviour: Relationship to demographics, perceived risk, and incentives. Health Marketing Quarterly 13(4): 33-46.

Nunnally JC, Bernstein, IH. 1994. Psychometric Theory (3rd ed). McGraw-Hill: New York.

Peterson RA. 2001. On the use of college students in social science research: Insights from a second-order meta analysis. Journal of Consumer Research 28(3): 450-461.

Popovsky MA. 2006. Understanding the donor can correct the nation's blood imbalance. Transfusion 46(4): 501-502.

Richins ML. 1983. Analysis of consumer interaction styles in the marketplace. Journal of Consumer Research 10(June): 73-82.

Sargeant A, Jay E. 2003. The fundraising performance of charity websites: A US/UK comparison. Journal of Interactive Marketing 4(4): 330-342.

Saxton J. 2001. The growth of the Internet, digital television and mobile telephony and the implications for not-for-profit marketing. International Journal of Nonprofit and Voluntary Sector Marketing 6(4): 347-363.

Saxton J. 2004. Editorial: The Achilles heel of modern non-profits is not public 'trust and confidence' but public understanding of $21^{\text {st }}$ century charities. International Journal of Nonprofit and Voluntary Sector Marketing 9(3): 188-170.

Schegelmilch BB, Love A, Diamantopoulos A. 1997. Responses to different charity appeals: The impact of donor characteristics and the amount of donations. European Journal of Marketing 31(8): 548-560.

Smith JD. 1999. Poor marketing or the decline of altruism? Young people and volunteering in the United Kingdom. International Journal of Nonprofit and Voluntary Sector Marketing 4(4): 372-377. 
Tscheulin DK, Lindenmeier J. 2005. The willingness to donate blood: An empirical analysis of socio-demographic and motivation-related determinants. Health Services Management 18(3): 265-174.

Zaichowsky JL. 1985. Measuring the Involvement Construct. Journal of Consumer Research 12(December): 341-352.

Zikmund, W. G., and Babin, B. J. (2007). Essentials of Marketing Research, $3^{\text {rd }}$ ed. Thomson South-Western, OH. 


\section{Appendix 1.}

Sample area

\section{Red Cross Blood Services Research Questionnaire.}

The aim of this research is to gain a better understanding of the Blood Service and its donors.

The results from this research will contribute to a greater insight of the service offered by the Blood Service and its publics.

The questionnaire should take about 9 - 11 minutes to complete. First we will ask you questions about donating, the Red Cross, and the blood service, then we'll ask about your media preferences.

All responses are completely anonymous. No findings that could identify any individual participant will be made known. The anonymity of your participation is assured by our procedure, in which the questionnaires are anonymous and only the combined results will be made known.

Your participation is completely voluntary and you may withdraw from completing the questionnaire at any stage. You may also avoid answering any questions that you feel are too personal or intrusive. 
When choosing whether to donate in any form or manner, people often base their choice on a variety of issues. Use the following questions to indicate how important each of the following is to you when making a decision to donate in any form or manner. (Please circle your answer for each statement)

\begin{tabular}{l|ccccccc} 
& $\begin{array}{c}\text { Strongly } \\
\text { Disagree }\end{array}$ & Disagree & $\begin{array}{c}\text { Slightly } \\
\text { Disagree }\end{array}$ & Neither & $\begin{array}{c}\text { Slightly } \\
\text { Agree }\end{array}$ & $\begin{array}{c}\text { Strongly } \\
\text { Agree }\end{array}$ \\
\hline $\begin{array}{l}\text { To me it is important that the donation } \\
\text { solves problems }\end{array}$ & 1 & 2 & 3 & 4 & 5 & 6 & 7 \\
$\begin{array}{l}\text { To me it is important the donation helps to } \\
\text { strengthen the community spirit }\end{array}$ & 1 & 2 & 3 & 4 & 5 & 6 & 7 \\
$\begin{array}{l}\text { To me it is important that the charity needs } \\
\text { financial assistance }\end{array}$ & 1 & 2 & 3 & 4 & 5 & 6 & 7 \\
$\begin{array}{l}\text { To me it is important that the Charity } \\
\text { provides quality services }\end{array}$ & 1 & 2 & 3 & 4 & 5 & 6 & 7 \\
$\begin{array}{l}\text { To me it is important that the donation is } \\
\text { used to assist people }\end{array}$ & 1 & 2 & 3 & 4 & 5 & 6 & 7 \\
\hline
\end{tabular}

Please circle the number that best represents your response to the following statements offered.

\begin{tabular}{|c|c|c|c|c|c|c|c|}
\hline & $\begin{array}{l}\text { Strongly } \\
\text { Disagree }\end{array}$ & Disagree & $\begin{array}{c}\text { Slightly } \\
\text { Disagree }\end{array}$ & Neither & $\begin{array}{c}\text { Slightly } \\
\text { Agree }\end{array}$ & Agree & $\begin{array}{c}\text { Strongly } \\
\text { Agree }\end{array}$ \\
\hline $\begin{array}{l}\text { The Red Cross tries to take advantage of } \\
\text { the community }\end{array}$ & 1 & 2 & 3 & 4 & 5 & 6 & 7 \\
\hline $\begin{array}{l}\text { The services offered by the Red Cross are } \\
\text { not as they should be }\end{array}$ & 1 & 2 & 3 & 4 & 5 & 6 & 7 \\
\hline $\begin{array}{l}\text { The Red Cross has helped to raise our } \\
\text { country's standard of living }\end{array}$ & 1 & 2 & 3 & 4 & 5 & 6 & 7 \\
\hline $\begin{array}{l}\text { The Red Cross organisation provides a } \\
\text { service to the community }\end{array}$ & 1 & 2 & 3 & 4 & 5 & 6 & 7 \\
\hline The Red Cross requires public support & 1 & 2 & 3 & 4 & 5 & 6 & 7 \\
\hline To me donating is unimportant & 1 & 2 & 3 & 4 & 5 & 6 & 7 \\
\hline Donating is a beneficial service & 1 & 2 & 3 & 4 & 5 & 6 & 7 \\
\hline Donating is just an extra burden & 1 & 2 & 3 & 4 & 5 & 6 & 7 \\
\hline To me donating is an essential service & 1 & 2 & 3 & 4 & 5 & 6 & 7 \\
\hline Donations are not really needed & 1 & 2 & 3 & 4 & 5 & 6 & 7 \\
\hline Society gives me a sense of security. & 1 & 2 & 3 & 4 & 5 & 6 & 7 \\
\hline It is important to feel a sense of belonging & 1 & 2 & 3 & 4 & 5 & 6 & 7 \\
\hline Being well respected is important to me & 1 & 2 & 3 & 4 & 5 & 6 & 7 \\
\hline
\end{tabular}


- Have you ever given blood? (Please tick)

- NO

YES

For this section, you are to circle the number that shows your feelings towards each of the following questions. (Please circle the appropriate answer)

\begin{tabular}{l|lllllllc} 
& $\begin{array}{l}\text { Highly } \\
\text { Improbable }\end{array}$ & & & Neutral & & $\begin{array}{c}\text { Highly } \\
\text { Probable }\end{array}$ \\
\hline $\begin{array}{l}\text { How likely is it that you would donate } \\
\text { money to the Red Cross }\end{array}$ & 1 & 2 & 3 & 4 & 5 & 6 & 7 \\
$\begin{array}{l}\text { How likely is it that you would donate } \\
\text { time to the Red Cross }\end{array}$ & 1 & 2 & 3 & 4 & 5 & 6 & 7 \\
$\begin{array}{l}\text { How likely is it that you would donate } \\
\text { goods to the Red Cross }\end{array}$ & 1 & 2 & 3 & 4 & 5 & 6 & 7 \\
\hline
\end{tabular}

Please rate each of the following forms of information media on their degree of importance to you. (Please circle the appropriate answer)

\begin{tabular}{l|ccccccc} 
& $\begin{array}{c}\text { Very } \\
\text { Unimportant }\end{array}$ & Unimportant & $\begin{array}{c}\text { Slightly } \\
\text { Unimportant }\end{array}$ & Neither & $\begin{array}{c}\text { Slightly } \\
\text { Important }\end{array}$ & Important & $\begin{array}{c}\text { Very } \\
\text { Important }\end{array}$ \\
\hline Television & 1 & 2 & 3 & 4 & 5 & 6 & 7 \\
Magazines & 1 & 2 & 3 & 4 & 5 & 6 & 7 \\
Newspapers & 1 & 2 & 3 & 4 & 5 & 6 & 7 \\
Radio & 1 & 2 & 3 & 4 & 5 & 6 & 7 \\
Pamphlets/Brochures & 1 & 2 & 3 & 4 & 5 & 6 & 7 \\
Internet & 1 & 2 & 3 & 4 & 5 & 6 & 7 \\
SMS messaging & 1 & 2 & 3 & 4 & 5 & 6 & 7 \\
Email & 1 & 2 & 3 & 4 & 5 & 6 & 7 \\
Direct mail & 1 & 2 & 3 & 4 & 5 & 6 & 7 \\
Telephone & 1 & 2 & 3 & 4 & 5 & 6 & 7 \\
\hline
\end{tabular}


The following demographic questions are for classification purposes only and will help us to gain a better profile of the participant.

- Your date of birth (Year)

- Gender (Please tick)

đ̊ Male

q Female

- What is your main vocation? (Please tick only one)

_ Student Non-student

- What is your country of birth?

- What is your country of permanent residence?

WE APPRECIATE AND THANK YOU FOR YOUR TIME

(:) 
Table 1: Sampling Environment

\begin{tabular}{lrr}
\hline & Frequency & Percent \\
\hline University & 202 & 26 \\
Shopping mall & 194 & 25 \\
General public area & 380 & 49 \\
\hline
\end{tabular}


Table 2: Sampling Distribution

\begin{tabular}{llrrrr}
\hline & & \multicolumn{3}{c}{ Vocation } \\
\multirow{2}{*}{ Gender } & & Student & \multicolumn{2}{c}{ Non-Student } \\
& Male & 192 & 54 & 244 & 58 \\
& Female & 164 & 46 & 176 & 42 \\
\hline Overall totals & & 356 & 46 & 420 & 54 \\
\hline
\end{tabular}


Table 3: Logistic Regression

\begin{tabular}{lccc}
\hline Predictors & B & Sig. & $\operatorname{Exp(B)}$ \\
\hline Student / Non- & .803 & .000 & 2.233 \\
Student & .054 & .544 & 1.055 \\
Social Values & & .870 \\
Importance of & -.139 & .285 & .870 \\
Charity & & .085 & 1.204 \\
Importance of Need & .185 & .301 \\
Attitudes Towards & .263 & .055 & 1.301 \\
Charity & & &
\end{tabular}


Table 4: Test for significance between groups

\begin{tabular}{lccc}
\hline Donation & Calculated F & Critical F & Reject Null Hypothesis \\
\hline Money & 7.30 & 2.37 & Yes \\
Time & 9.38 & 2.37 & Yes \\
Goods & 4.05 & 2.37 & Yes \\
\hline
\end{tabular}


Table 5: Intentions towards other donation activities

\begin{tabular}{|c|c|c|c|c|c|c|c|c|c|c|}
\hline \multirow{2}{*}{$\begin{array}{l}\text { Donation } \\
\text { activity }\end{array}$} & \multirow[b]{2}{*}{ Sample } & \multirow[b]{2}{*}{$\mathrm{R}^{2}$} & \multicolumn{2}{|c|}{$\frac{\text { Social }}{\text { values }}$} & \multicolumn{2}{|c|}{$\frac{\text { Importance of }}{\text { Charity }}$} & \multicolumn{2}{|c|}{$\frac{\text { Importance }}{\text { of Need }}$} & \multicolumn{2}{|c|}{$\begin{array}{l}\frac{\text { Attitude }}{\text { towards }} \\
\text { Charity }\end{array}$} \\
\hline & & & B & $\mathrm{t}$ & $\mathrm{B}$ & $\mathrm{t}$ & $\mathrm{B}$ & $\overline{\mathrm{t}}$ & $\mathrm{B}$ & $\mathrm{t}$ \\
\hline \multirow[t]{2}{*}{ Money } & Student $^{\tau}$ & $.106^{*}$ & -.002 & .978 & .507 & $.000 * *$ & .019 & .845 & .325 & $.011 *$ \\
\hline & Non-student ${ }^{\tau}$ & $.080 *$ & .021 & .819 & .041 & .777 & .481 & $.000 * *$ & .066 & .640 \\
\hline \multirow[t]{2}{*}{ Time } & Student $^{\tau}$ & $.094^{*}$ & .013 & .891 & .360 & $.007 * *$ & .146 & .195 & .411 & $.005 * *$ \\
\hline & Non-student ${ }^{\tau}$ & .011 & .023 & .831 & .072 & .665 & .062 & .636 & .167 & .303 \\
\hline \multirow[t]{2}{*}{ Goods } & Student $^{\tau}$ & $.114^{*}$ & -.052 & .525 & .312 & $.006 * *$ & .315 & $.001 * *$ & .216 & .074 \\
\hline & Non-student ${ }^{\tau}$ & $.104^{*}$ & -.058 & .522 & -.001 & .997 & .625 & $.000 * *$ & -.060 & .662 \\
\hline
\end{tabular}


Table 6: Importance of media sources

\begin{tabular}{llclcc}
\hline Ranking & Media & $\begin{array}{c}\text { Combined } \\
\text { mean }\end{array}$ & Sample & $\begin{array}{c}\text { Individual } \\
\text { Mean }\end{array}$ & $\begin{array}{c}\text { Std. } \\
\text { Deviation }\end{array}$ \\
\hline 1 & Phone & 6.26 & Student & 6.25 & 1.25 \\
& & & Non-Student & 6.26 & 1.31 \\
\hline 2 & Television & 5.99 & Student & 6.06 & 1.09 \\
& & & Non-Student & 5.93 & 1.28 \\
\hline 3 & Email * & \multirow{2}{*}{5.92} & Student & 6.42 & 1.00 \\
& & & Non-Student & 5.43 & 1.81 \\
\hline 4 & Newspaper & \multirow{2}{*}{5.70} & Student & 5.69 & 1.24 \\
& & & Non-Student & 5.71 & 1.37 \\
\hline 5 & Radio & \multirow{2}{*}{5.30} & Student & 5.23 & 1.49 \\
& & & Non-Student & 5.37 & 1.52 \\
\hline 7 & Internet* & 5.07 & Student & 5.48 & 1.57 \\
& & & Non-Student & 4.70 & 1.83 \\
\hline 8 & Direct mail & \multirow{2}{*}{4.98} & Student & 4.93 & 1.58 \\
& & & Non-Student & 4.99 & 1.72 \\
\hline 9 & Magazines & \multirow{2}{*}{4.96} & Student & 5.05 & 1.40 \\
& & & Non-Student & 4.86 & 1.65 \\
\hline 10 & SMS* & \multirow{2}{*}{4.70} & Student & 5.05 & 1.82 \\
& & & Non-Student & 4.34 & 2.04 \\
\hline \multirow{2}{*}{ Pamphlets } & \multirow{2}{*}{4.03} & Student & 4.04 & 1.67 \\
& & & Non-Student & 4.02 & 1.80 \\
\hline
\end{tabular}

*: significant at the .01 level. 
Figure 1: Importance of Email

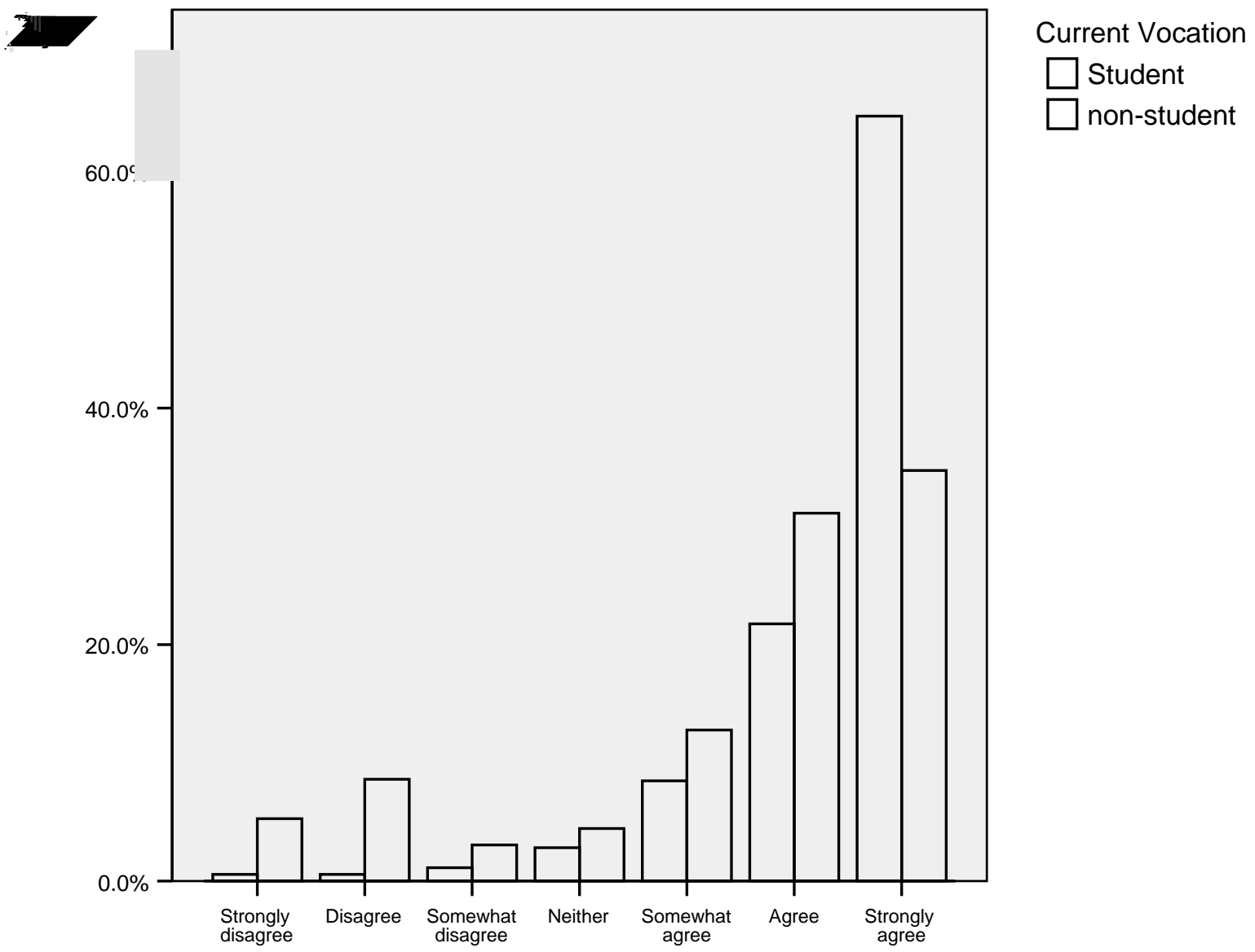


Figure 2: Importance of Internet

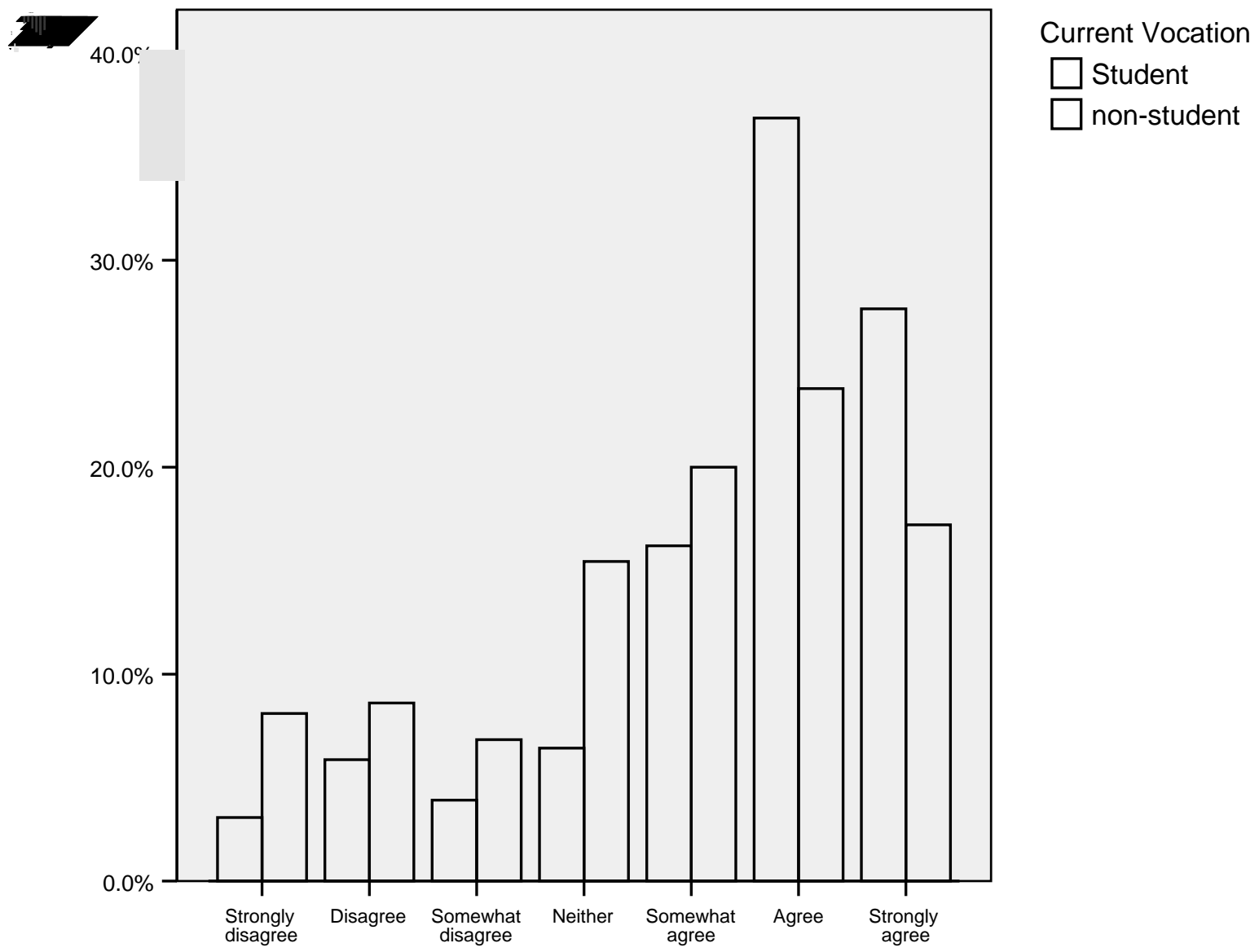


Figure 3: Importance of SMS

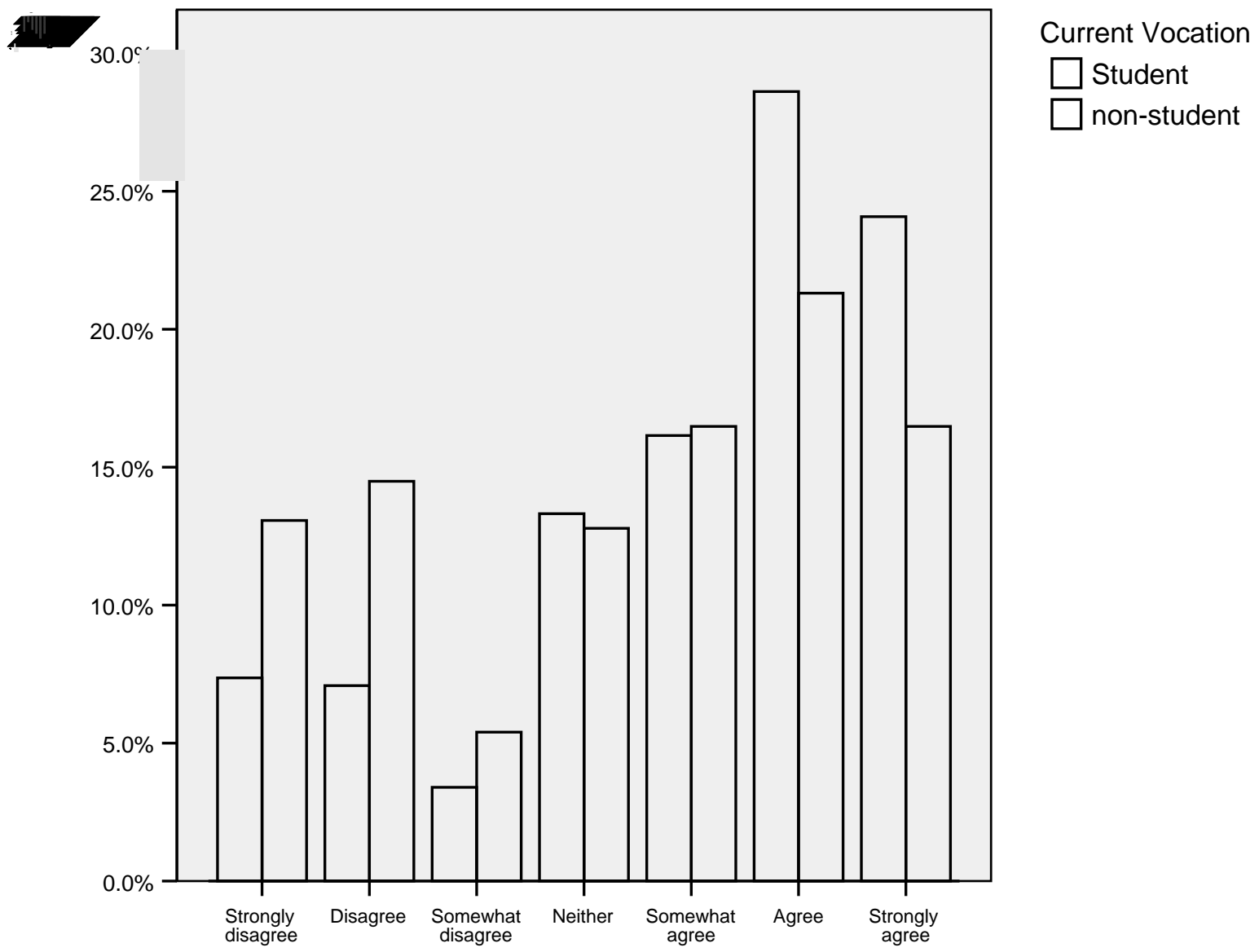

